\title{
Geology and petrology of the Hirao Limestone and the Tagawa metamorphic rocks-with special reference to the contact metamorphism by Cretaceous granodiorite
}

\author{
Mayuko FuKUYAMA $^{*}$, Kensaku URATA $^{* *}$ and Tadao NishiYAMA ${ }^{* * *}$ \\ * Graduate School of Science and Technology, Kumamoto University, Kurokami 2-39-1, Kumamoto 860-8555 \\ ** Department of Geography, Tokyo Metropolitan University, Minami-Osawa 1-1, Hachioji, Tokyo 192-0397 \\ ***: Department of Earth Sciences, Kumamoto University, Kurokami, 2-39-1, Kumamoto 860-8555
}

\begin{abstract}
The Hirao Limestone located in northeast Kyushu is bordered on the north by unmetamorphosed Paleozoic strata (the Kagumeyoshi Formation), and on the south by the Tagawa metamorphic rocks, a member of the Sangun Metamorphic Rocks. They are thermally metamorphosed due to the Cretaceous Hirao granodiorite intrusion. As a result, neither the fossil record nor the record of the regional (Sangun) metamorphism has been preserved. We investigated the geologic relationships among these units. The tectonic collage model associated with accretionary processes proposed by Kanmera and Nishi (1983) seems the most reasonable. The Hirao Limestone and the uppermost part of the Tagawa metamorphic rocks may be a large olistolith formed during the accretion of the Palaeozoic formation.

Petrological studies show that the area was thermally metamorphosed as revealed by widespread occurrences of biotite in pelitic rocks both in the Tagawa metamorphic rocks and in the Kagumeyoshi Formation. Garnet occurrences in the pelitic schists close to the Hirao granodiorite suggest about $700^{\circ} \mathrm{C}$ for the peak metamorphic temperature of contact metamorphism, based on garnet-biotite geothermometers. The high temperature condition is consistent with the occurrence of corundum in quartz-free layers of the pelitic schist, and that of anthophyllite in quartz-free layers of the basic schists consisting of hornblende + plagioclase. These lines of evidence are indicative of the amphibolite facies condition of contact metamorphism.
\end{abstract}

\section{Introduction}

The Sangun Terrane is widely distributed in the Inner Zone of Southwest Japan which consists of the Sangun Metamorphic Rocks, a non to weakly metamorphosed Paleozoic formation, chert facies of the Permian-TriassicJurassic system, and shallow marine to brackish water sedimentary facies of the Triassic-Jurassic system (Hase and Nishimura, 1979; Hayasaka, 1985). Previous studies of radiolarian fossils from the Paleozoic formation (e.g. Ishiga, 1984) clarified that it is of middle to late Permian age. One of the main objectives of the study of the Terrane is to clarify the relationship between the Sangun Metamorphic Rocks and the non to weakly metamorphosed Paleozoic formation. Nureki (1969) suggested that the Sangun Metamorphic Rocks underlie the Pa-

M. Fukuyama,mayuko@es.sci.kumamoto-u.ac.jp Corresponding author

K. Urata, CYR00601@nifty.ne.jp

T. Nishiyama, tadao@sci.kumamoto-u.ac.jp leozoic formation with some tectonic contacts and there is a chronological gap between the sedimentary ages of these two formations. On the other hand, Nishimura et al. (1977) argued that they are conformable geologic units in terms of both stratigraphy and metamorphism because the Sangun Metamorphic Rocks have escaped the burial metamorphism which took place in the Paleozoic formation. Hara (1982) pointed out that the Sangun Metamorphic Rocks commonly overlie the Lower Jurassic formation, and he concluded that the metamorphic rocks were emplaced as many nappes from the tectonic position of glaucophanitic metamorphism. He also proposed that the nappe of the Paleozoic formation overlies that of the Sangun Metamorphic Rocks.

The other important point is the origin of large limestone bodies of Early Carboniferous-Middle Permian age sporadically distributed in the Inner Zone of Southwest Japan. In the study of the Akiyoshi Limestone, Kanmera and Nishi (1983) proposed a new interpretation of the origin of the Paleozoic formation, which consists of accreted reef limestones, coeval pelagic siliceous deposits 
and trench-fill terrigenous sediments.

One of the large limestone bodies, the Hirao Limestone, occurs in northern Kyushu between the Tagawa metamorphic rocks (a member of the Sangun Metamorphic Rocks) and the Kagumeyoshi Formation (a member of non to weakly metamorphosed Paleozoic formation).

Geological relationships between these units are poorly understood, partly because they have been subjected to extensive contact metamorphism associated with Cretaceous granite intrusions. The overprinting of contact metamorphism renders it difficult to apply the well accepted interpretation of structural subdivision of the Sangun Metamorphic Belt into the Suo and Chizu Belts (Nishimura, 1998) to northern Kyushu, as the subdivision was established mainly by radiometric dating of metamorphic minerals. In this context we need to evaluate the effect of contact metamorphism.

The aims of this paper are to discuss the geological relationships between the Kagumeyoshi Formation and the Hirao Limestone, and those between the Hirao Limestone and the Tagawa metamorphic rocks based on the several new field observations. We also discuss the nature of the contact metamorphism in terms of pressure and temperature conditions.

\section{Geology}

The Hiraodai area, located in the south of Kita-Kyushu City, provides an excellent opportunity to investigate the geologic and tectonic framework of the basement rocks in north Kyushu, because the Kagumeyoshi Formation ("non to weakly metamorphosed Paleozoic formation" in the sense that it escaped or was only weakly affected by the Sangun Metamorphism), the Hirao Limestone and the Tagawa metamorphic rocks occur in this order from north to south, trending NE-SW. These three geologic units were intruded by the Hirao granodiorite (biotite $\mathrm{K}$ - Ar age of 94 Ma, Kawano and Ueda, 1966) in eastern Hiraodai and have undergone extensively the contact metamorphism. The Hirao Limestone is bounded on the western side by the Kokura-Tagawa tectonic line ( $\mathrm{N}-\mathrm{S}$ trending active fault) (Fig.1).

The relation between the Kagumeyoshi Formation and the Hirao Limestone has been interpreted either as a fault contact (Matsumoto, 1951; Kinoshita, 1953; Kinoshita et al., 1954) or as a conformity (Kiyohara,

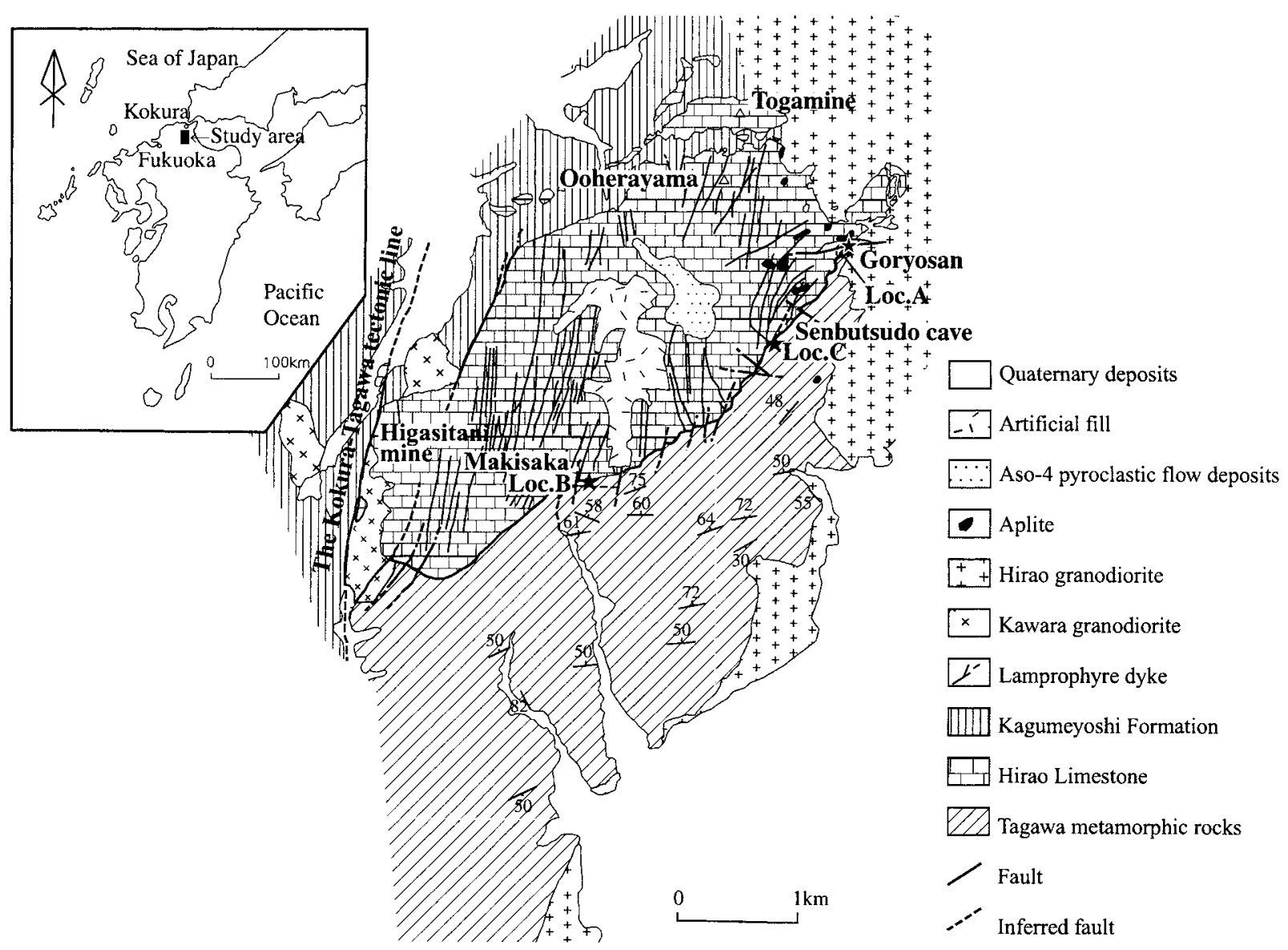

Figure 1. Geologic map around the Hirao Limestone at the Hiraodai area, Kokura, north Kyushu (after Urata et al., 1997). 
1968; Matsushita et al., 1969; Matsushita, 1971). A similar argument has been made for the relationship between the Hirao Limestone and the Tagawa metamorphic rocks. Some workers interpreted it as a fault contact (Kiyohara, 1968; Matsushita et al., 1969; Matsushita, 1971) but others proposed a conformable relationship (Matsumoto, 1951; Kinoshita, 1953; Kinoshita et al., 1954). Another important geological argument is Kiyohara's (1968) discussion on the unconformity within the Hirao Limestone. In this paper we present several new observations which provide key information to understanding the geologic and tectonic framework of this area.

\section{Relationship between the Kagumeyoshi Formation and the Hirao Limestone}

The Kagumeyoshi Formation (Matsushita et al., 1969) consists mainly of sandstone and shale with subordinate amounts of conglomerate, chert, siliceous shale, greenrock, and limestone. Permian fossils were reported from a small limestone body at the Kiku Peninsula, about $20 \mathrm{~km}$ northeast of the studied area. The Kagumeyoshi Formation is believed to have escaped the Sangun Metamorphism but it have undergone the contact metamorphism by the Hirao granodiorite intrusion, resulting in the formation of wollastonite and biotite in rocks close to the granodiorite.

The boundary between the Kagumeyoshi Formation and the Hirao Limestone is observed along the north border of the Hirao Limestone (Figs. 1 and 2). The Kagumeyoshi Formation along the border consists of siliceous shale trending EW with dips of $55^{\circ} \mathrm{S}-90^{\circ}$. Limestone at the boundary thinly mingled with siliceous shale layer by layer (Fig. 2). At first glance it looks like a thin alternation, however, the layers are interconnected like a flattened network vein. The thickness of each layer in the mingled part ranges from several millimeters to several centimeters. Wollastonite layers occur between the limestone and siliceous shale layers (both are recrystallized) within the limits of $1 \mathrm{~km}$ from the intrusive contact of the Hirao granodiorite. Small bodies of limestone (from several meters to 100 meters in thickness) occur in siliceous and ordinary shale layers in various horizons near the intrusive contact. A relatively larger body of limestone ( $0.3 \mathrm{~km}$ by $1.5 \mathrm{~km}$ in size) occurs at the Togamine area, forming a topographic high.

\section{Relationship between the Hirao Limestone and the Tagawa metamorphic rocks}

The Tagawa metamorphic rocks consist mainly of pelitic schist with small amounts of basic schist, siliceous schist,

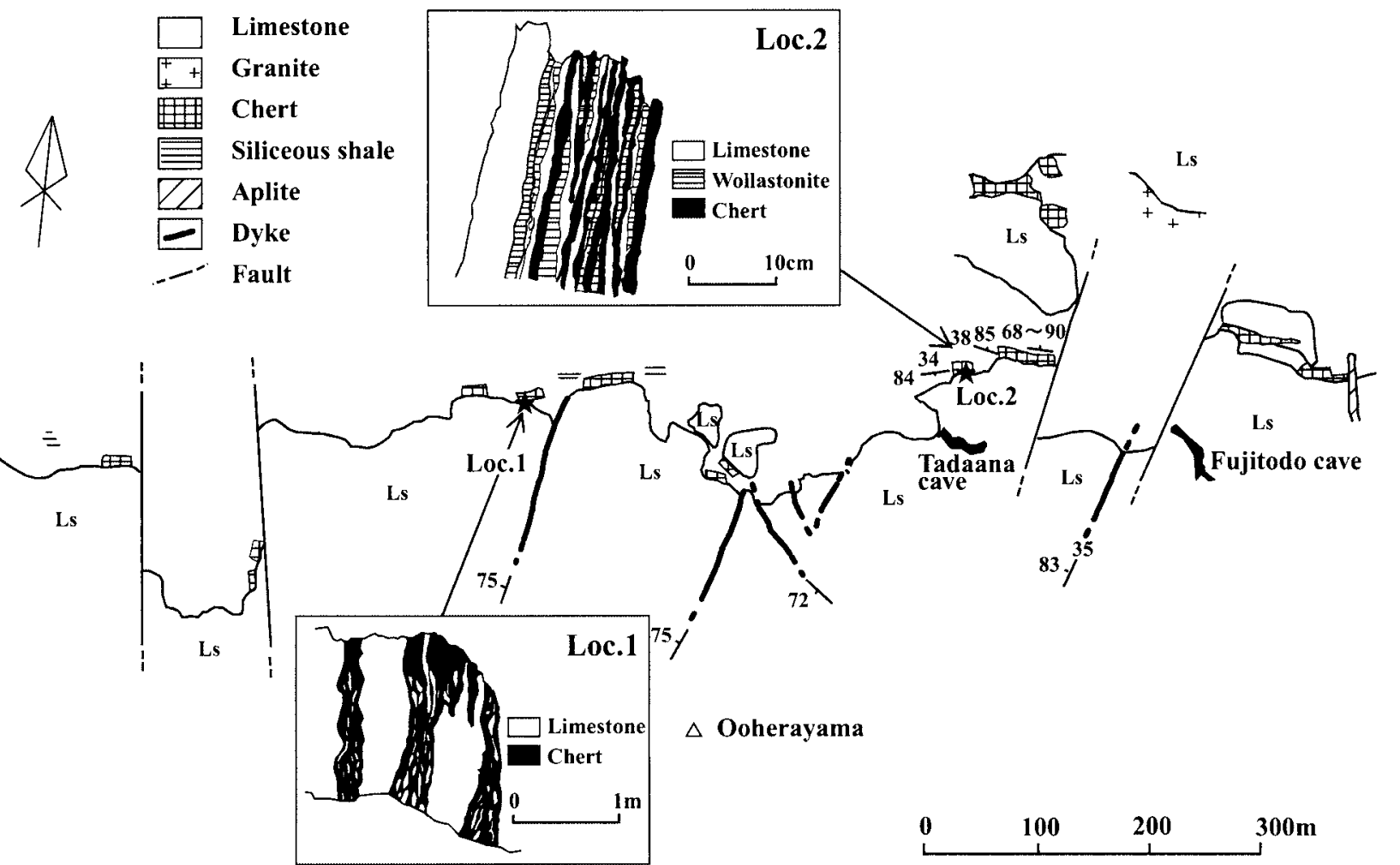

Figure 2. Route map in the northwestern border of the Hirao Limestone with the Kagumeyoshi Formation. Boxes are sketches of outcrops showing the relation between the Kagumeyoshi Formation and the Hirao Limestone (after Urata, 1987MS). Ls, the crystalline limestone. 
and calcareous schist, trending NE-SW and dipping $50^{\circ}-70^{\circ} \mathrm{N}$. In some cases, the pelitic and basic layers alternate with each other on the scale of millimeters. The amount of calcareous schist increases close to the contact with the Hirao Limestone.

The contact between the Hirao Limestone and the Tagawa metamorphic rocks is either a concordant relation or a fault. The fault contact is observed at Senbutsudo cave, where a fracture zone is bounded by a fault trending $\mathrm{NE}-\mathrm{SW}$ and dipping $60^{\circ} \mathrm{N}-90^{\circ}$. The fault has created a steep cliff near the boundary. The fault extends into the Hirao granodiorite and is cut in many places by $\mathrm{N}-\mathrm{S}$ trending faults, which are parallel to the Kokura-Tagawa tectonic line. These observations suggest that the NESW fault developed after the intrusion of the Hirao granodiorite.
We found several outcrops from which we identified a clear stratigraphic relationship between the Hirao Limestone and the Tagawa metamorphic rocks prior to the development of the NE-SW fault as described below.

\section{(a) The outcrop at Goryosan}

As shown in Figure 3, the Goryosan outcrop about 100 $\mathrm{m}$ from the intrusive contact with the Hirao granodiorite shows clear boundary features between the Hirao Limestone and the Tagawa metamorphic rocks. Both of the Hirao Limestone and the Tagawa metamorphic rocks have been extensively recrystallized. But the latter still preserved a schistose structure. They consisted mainly of basic schists alternating with thin pelitic schists. At the boundary the Hirao Limestone contains several layers of the Tagawa metamorphic rocks (several centimeters
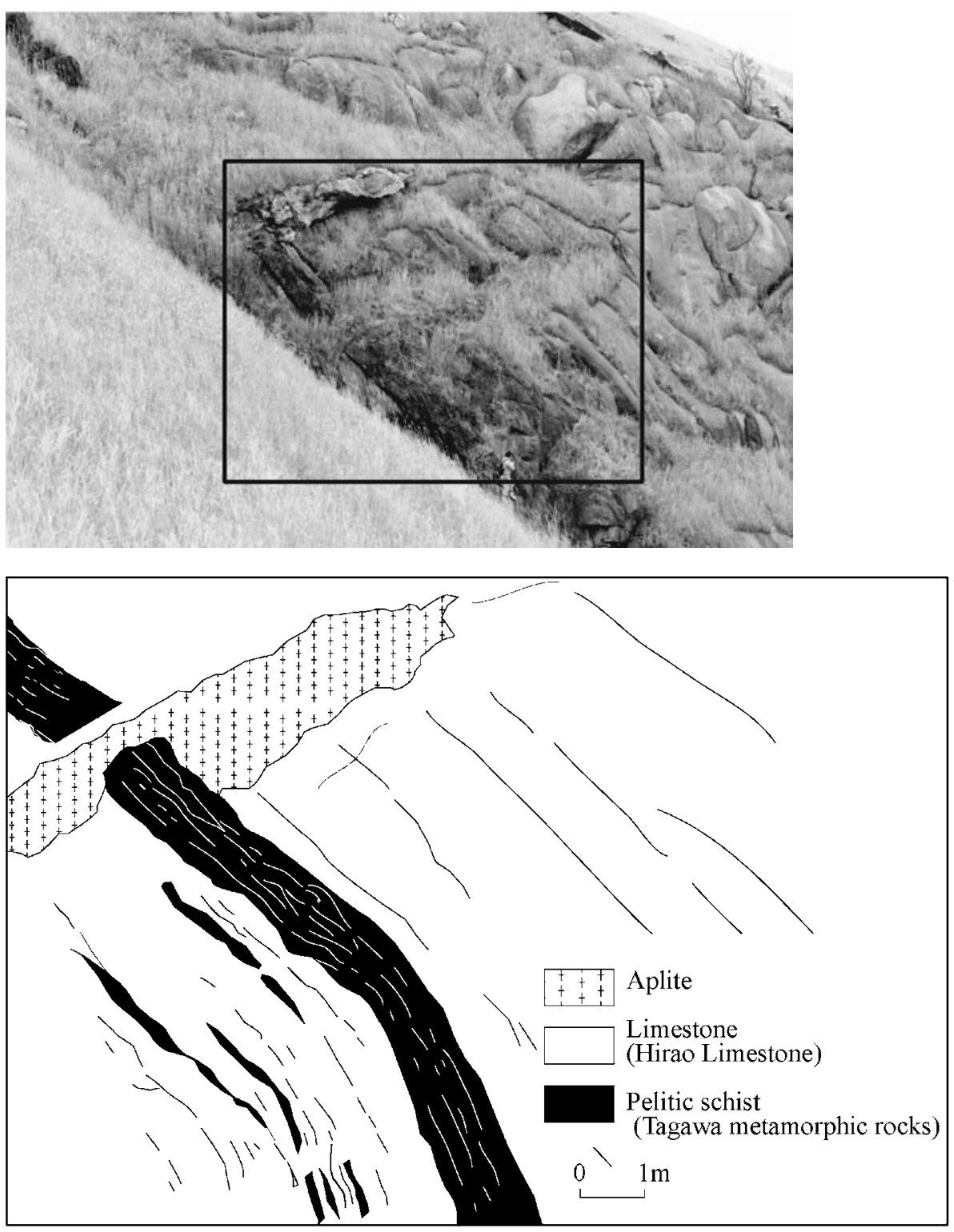

Figure 3. Sketch of an outcrop showing the concordant relationship between the Tagawa metamorphic rocks and the Hirao Limestone at locality A (Goryosan) in Figure 1. 


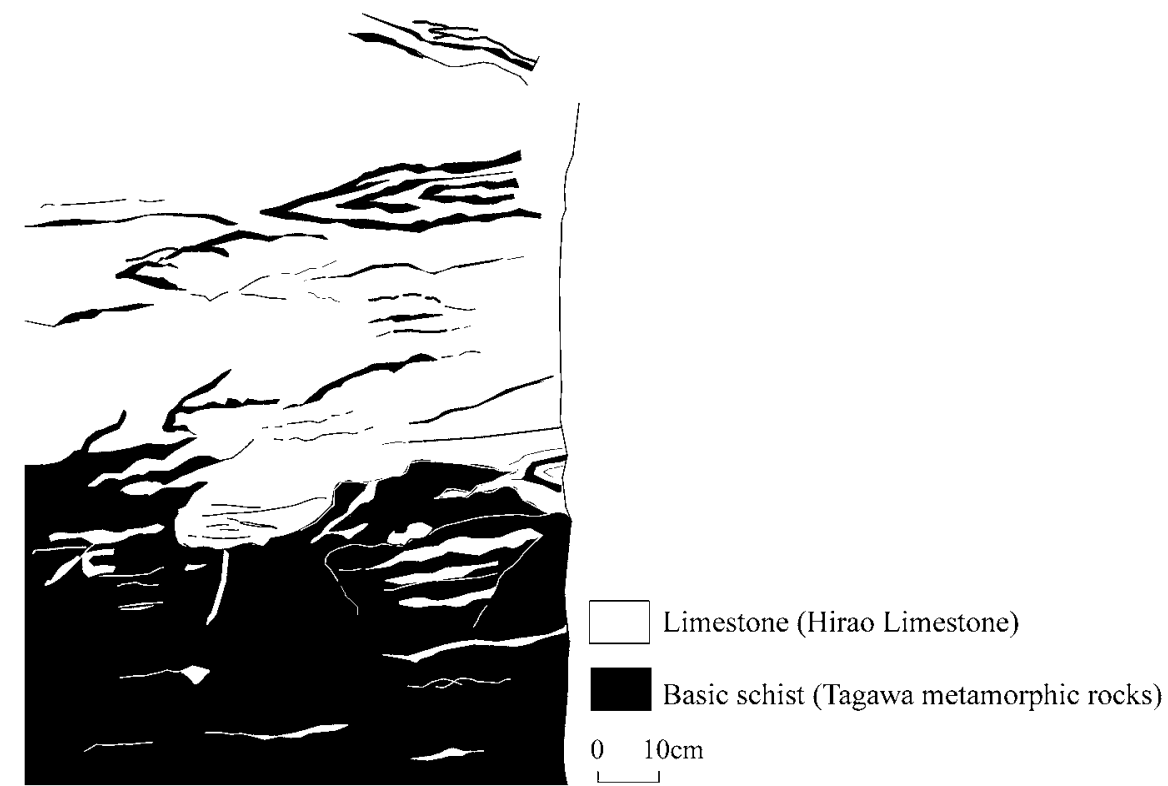

Figure 4. Sketch of an outcrop showing the conformity relationship between the Tagawa metamorphic rocks and the Hirao Limestone at locality B (Makisaka).

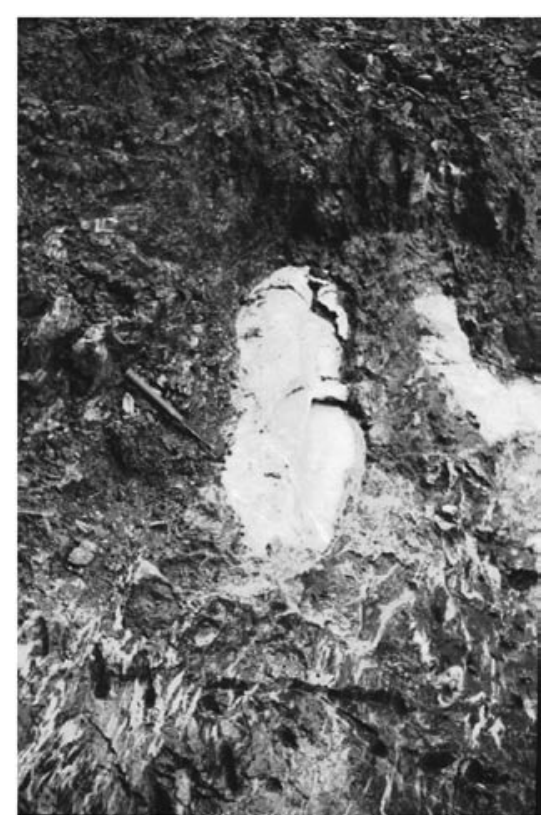

(a)

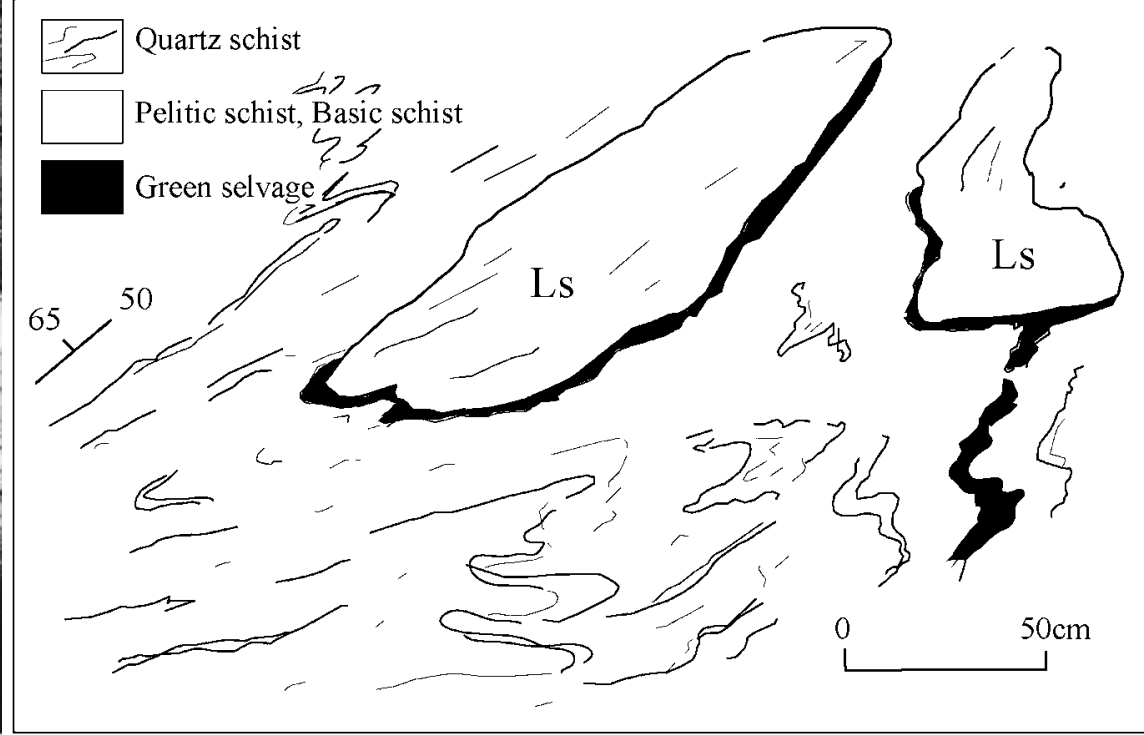

(b)

Figure 5. Modes of occurrence of the Tagawa metamorphic rocks near the contact with the Hirao Limestone at locality C (Senbutsudo cave) in Figure 1. (a) Photograph of some lenticular bodies of the crystalline limestone occurred in the Tagawa metamorphic rocks. The size of lenticular body is $0.4 \times 1.2 \mathrm{~m}$. (b) Sketch of the Tagawa metamorphic rocks consists of quartz schists, basic schists and pelitic schists, which show complicated and tight foldings. Ls, the crystalline limestone.

to one meter thick), where no fault is observed between them. Some skarn-like rocks consisting of diopside and garnet occurred at the boundaries between basic schist layers and the crystalline limestones. (b) The outcrop at Makisaka

At this outcrop, we observed a gradational change from the Tagawa metamorphic rocks to the Hirao Limestone. The Tagawa metamorphic rocks consist of basic schist layers at a lower part of this outcrop. Towards the top, 
lithology changes from the basic schist to an alternation of basic and calcareous schists. The upper part of this outcrop consists of the crystalline limestone intercalated with thin basic schist layer several millimeters thick. In some places, the basic schist layer shows a rootless intrafolial fold (Fig.4) with an axial plane parallel to the schistosity $\left(\mathrm{N} 43^{\circ} \mathrm{W}, 34^{\circ} \mathrm{NE}\right)$, suggesting ductile deformation associated with the Sangun metamorphic event. The calcareous schist in the Tagawa metamorphic rocks is similar to the crystalline limestone of the Hirao Limestone.

(c) The outcrop at the Senbutsudo cave

We observed a new outcrop at a construction site near the Senbutsudo cave about $15 \mathrm{~m}$ below the exposed boundary between the Hirao Limestone and the Tagawa metamorphic rocks, however this outcrop was cemented after our observation. The Tagawa metamorphic rocks at this outcrop consisted of an alternation of quartz schist, basic schist, and pelitic schist, and showed a tight folding. Some lenticular bodies of crystalline limestone (up to
$0.4 \times 1.2 \mathrm{~m}$ in size) occurred in the metamorphic rocks (Fig. 5). A green selvage consisting of diopside and calcite developed around the lens.

\section{Dyke swarms in the Hirao Limestone}

The Hirao Limestone contains a large numbers of thin (several centimeters to several meters thick) basic dykes which are cut by aplite dykes in several places. Within the limits of about $1 \mathrm{~km}$ from the intrusive contact with the Hirao granodiorite, the basic dykes have undergone the contact metamorphism to hornfels and reaction zones developed between the dykes and the limestone (Nishiyama, 1989). With increasing distance from the intrusive contact, the reaction zone becomes obscure and the dyke exhibits a porphyritic igneous texture. Locations of most of the dykes shown in Figure 1 are confirmed by one of the authors (K.U.) in several caves, and it is difficult to observe them on the surface because they are frequently weathered to clay zones. They generally trend

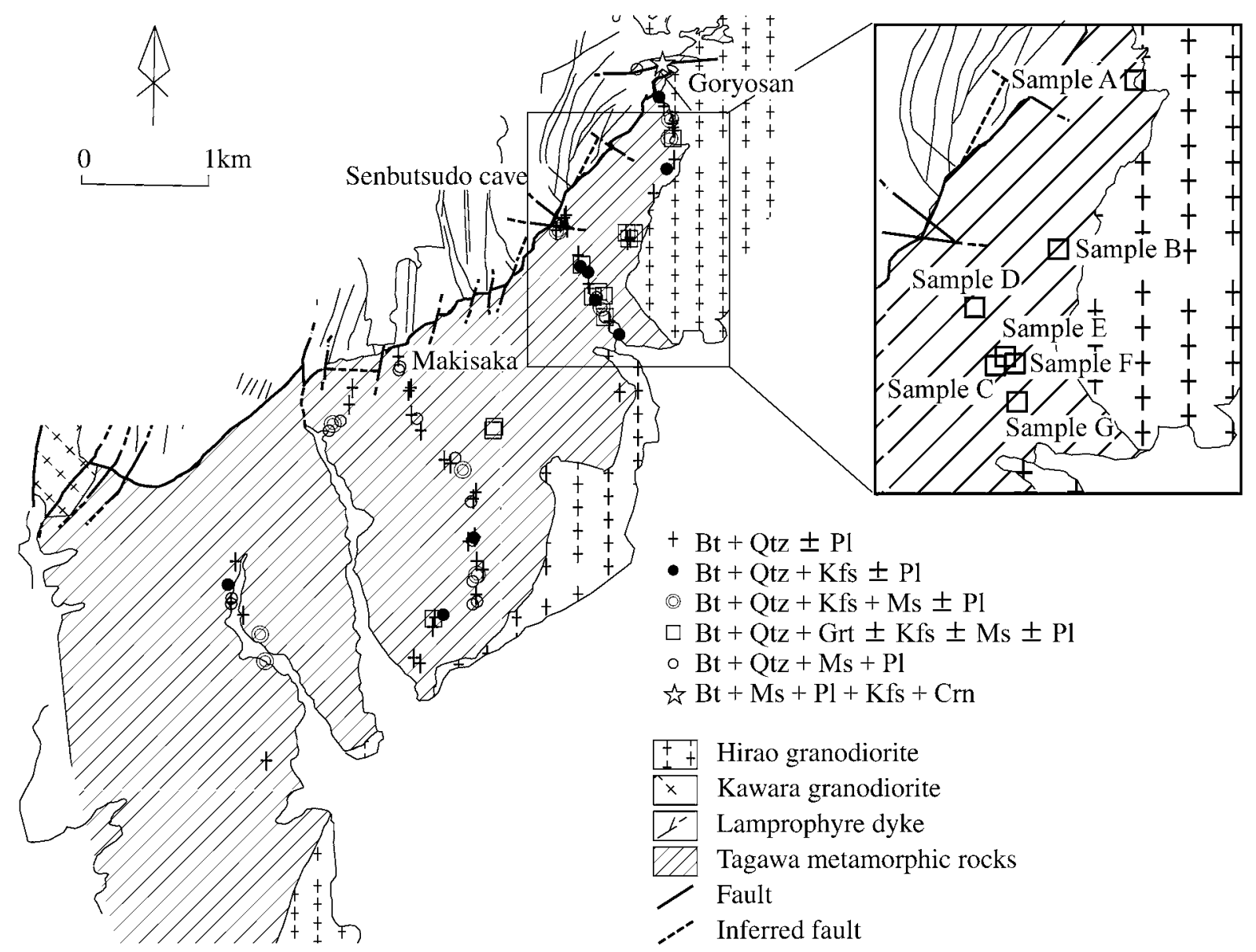

Figure 6. Distribution of the mineral assemblages of pelitic schists in the Tagawa metamorphic rocks. Sample A to G indicate the locations of garnets coexisting with biotite which were listed in Table 1 and used in other Figures. Abbreviations of mineral names are after Kretz (1983). 
Table 1. Electron probe microanalyses of garnet and biotite in pelitic schists

\begin{tabular}{|c|c|c|c|c|c|c|c|}
\hline \multicolumn{8}{|c|}{ Garnet } \\
\hline Sample & A & $\mathrm{B}$ & $\mathrm{C}$ & $\mathrm{D}$ & $\mathrm{E}$ & $\mathrm{F}$ & $\mathrm{G}$ \\
\hline$\overline{\mathrm{SiO}_{2}}$ & 37.93 & 36.59 & 36.54 & 37.33 & 36.74 & 36.31 & 37.08 \\
\hline $\mathrm{Al}_{2} \mathrm{O}_{3}$ & 20.91 & 20.69 & 20.48 & 20.95 & 20.91 & 20.54 & 20.71 \\
\hline $\mathrm{FeO}^{*}$ & 31.22 & 29.64 & 29.20 & 30.10 & 29.95 & 36.31 & 28.49 \\
\hline $\mathrm{MnO}$ & 7.53 & 9.71 & 10.49 & 8.61 & 9.30 & 8.12 & 9.82 \\
\hline $\mathrm{MgO}$ & 2.50 & 2.32 & 1.89 & 1.71 & 1.62 & 2.32 & 2.89 \\
\hline $\mathrm{CaO}$ & 1.40 & 0.41 & 0.68 & 0.45 & 1.49 & 0.49 & 1.41 \\
\hline total & 101.49 & 99.36 & 99.27 & 99.15 & 100.01 & 99.93 & 100.04 \\
\hline \multicolumn{8}{|c|}{ Cations on the basis of 12 Oxygens } \\
\hline $\mathrm{Si}$ & 3.02 & 2.99 & 3.00 & 3.04 & 2.99 & 2.97 & 2.99 \\
\hline $\mathrm{Al}$ & 1.96 & 2.00 & 1.98 & 2.01 & 2.01 & 1.98 & 1.97 \\
\hline $\mathrm{Fe}$ & 2.08 & 2.03 & 2.01 & 2.05 & 2.04 & 2.20 & 1.92 \\
\hline $\mathrm{Mn}$ & 0.51 & 0.67 & 0.73 & 0.59 & 0.64 & 0.56 & 0.67 \\
\hline $\mathrm{Mg}$ & 0.30 & 0.28 & 0.23 & 0.21 & 0.20 & 0.28 & 0.35 \\
\hline $\mathrm{Ca}$ & 0.12 & 0.04 & 0.06 & 0.04 & 0.13 & 0.04 & 0.12 \\
\hline total & 7.99 & 8.01 & 8.01 & 7.95 & 8.01 & 8.04 & 8.02 \\
\hline $\mathrm{Mg} /(\mathrm{Mg}+\mathrm{Fe})$ & 0.144 & 0.138 & 0.114 & 0.102 & 0.089 & 0.113 & 0.154 \\
\hline \multicolumn{8}{|c|}{ Biotite } \\
\hline Sample & $\mathrm{A}$ & $\mathrm{B}$ & $\mathrm{C}$ & $\mathrm{D}$ & $\mathrm{E}$ & $\mathrm{F}$ & $\mathrm{G}$ \\
\hline$\overline{\mathrm{SiO}_{2}}$ & 37.71 & 36.92 & 35.24 & 34.14 & 35.91 & 34.32 & 35.94 \\
\hline $\mathrm{TiO}_{2}$ & 3.32 & 2.82 & 2.17 & 2.43 & 2.70 & 1.98 & 2.89 \\
\hline $\mathrm{Al}_{2} \mathrm{O}_{3}$ & 18.19 & 18.70 & 18.95 & 18.51 & 17.99 & 18.51 & 18.25 \\
\hline $\mathrm{FeO}^{*}$ & 20.74 & 30.52 & 20.95 & 22.42 & 22.20 & 21.68 & 21.28 \\
\hline $\mathrm{MnO}$ & 0.21 & 0.32 & 0.41 & 0.36 & 0.50 & 0.61 & 0.54 \\
\hline $\mathrm{MgO}$ & 8.79 & 8.25 & 7.27 & 6.34 & 7.16 & 7.86 & 8.67 \\
\hline $\mathrm{K}_{2} \mathrm{O}$ & 9.79 & 10.17 & 10.02 & 10.13 & 10.96 & 11.17 & 11.10 \\
\hline total & 98.75 & 97.70 & 95.01 & 94.34 & 97.42 & 96.13 & 98.67 \\
\hline \multicolumn{8}{|c|}{ Cations on the basis of 22 Oxygens } \\
\hline $\mathrm{Si}$ & 5.34 & 5.52 & 5.46 & 5.38 & 5.46 & 5.32 & 5.37 \\
\hline $\mathrm{Ti}$ & 0.38 & 0.32 & 0.26 & 0.60 & 0.31 & 0.23 & 0.32 \\
\hline $\mathrm{Al}$ & 3.30 & 3.30 & 3.46 & 3.44 & 3.22 & 3.38 & 3.22 \\
\hline $\mathrm{Fe}$ & 2.66 & 2.56 & 2.72 & 2.96 & 2.82 & 2.81 & 2.66 \\
\hline $\mathrm{Mn}$ & 0.04 & 0.04 & 0.06 & 0.06 & 0.06 & 0.08 & 0.07 \\
\hline $\mathrm{Mg}$ & 2.02 & 1.84 & 1.68 & 1.50 & 1.62 & 1.82 & 1.93 \\
\hline $\mathrm{K}$ & 1.92 & 1.94 & 1.98 & 2.04 & 2.12 & 2.21 & 2.12 \\
\hline total & 15.66 & 15.52 & 15.62 & 15.68 & 15.61 & 15.86 & 15.69 \\
\hline $\mathrm{Mg} /(\mathrm{Mg}+\mathrm{Fe})$ & 0.432 & 0.418 & 0.382 & 0.336 & 0.365 & 0.393 & 0.420 \\
\hline
\end{tabular}

${ }^{*}$ Total iron as $\mathrm{FeO}$.

NS with dips of $70^{\circ} \mathrm{N}$ or S- $90^{\circ}$. More than 100 dykes were observed. A small number of the similar dykes also occur in the Kagumeyoshi Formation adjacent to the Hirao Limestone. We also found a few basic dykes in the uppermost part of the Tagawa metamorphic rocks.

\section{Petrography and mineral chemistry}

Quantitative chemical analyses of minerals were performed with an energy dispersive $\mathrm{X}$-ray microanalyser JOEL SEM JSM-5600 combined with LINK ISIS system at Kumamoto University. The acceleration voltage was $20 \mathrm{kV}$, electron beam current was set to $0.6 \mathrm{nA}$.

\section{The Tagawa metamorphic rocks}

(a) Pelitic schists

Pelitic schists in the Tagawa metamorphic rocks are black in color due to abundant carbonaceous material. They are fine-grained (about several 10 micrometers in grain size) but become coarser-grained (up to several millimeters) as they approach the Hirao granodiorite. The rocks ex- 


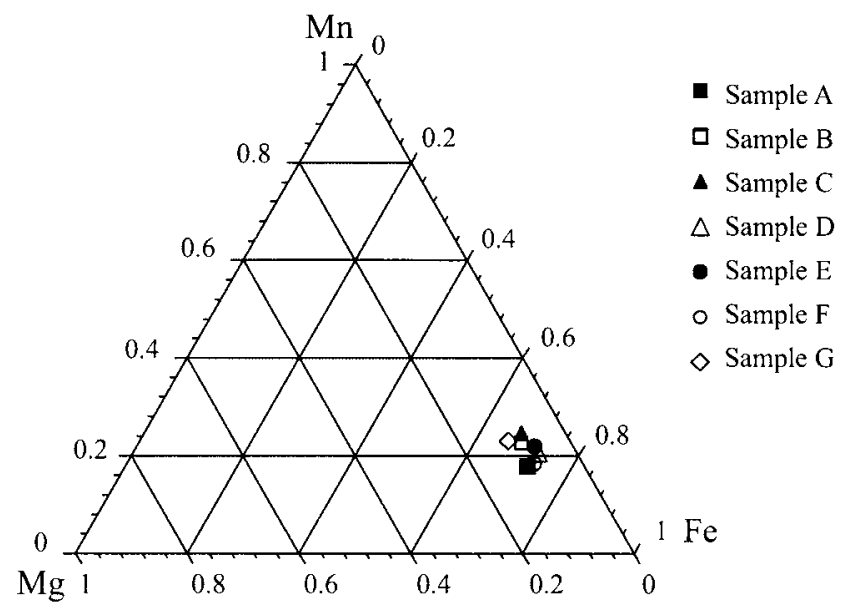

Figure 7. Spessartine (Mn)-almandine ( $\mathrm{Fe}$ )-pyrope $(\mathrm{Mg})$ diagram showing compositional ranges of garnet in pelitic schists from the Tagawa metamorphic rocks.

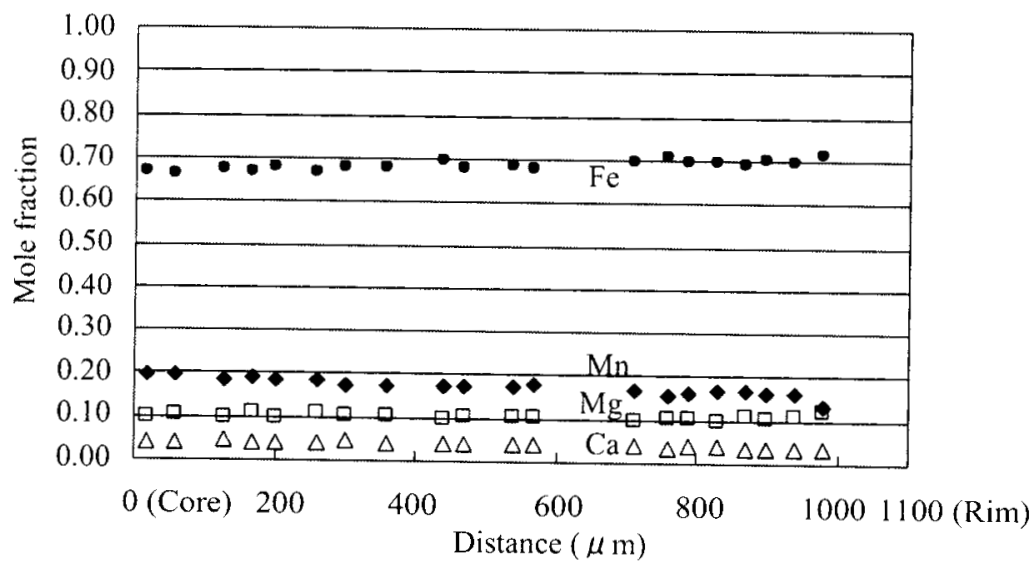

Sample A

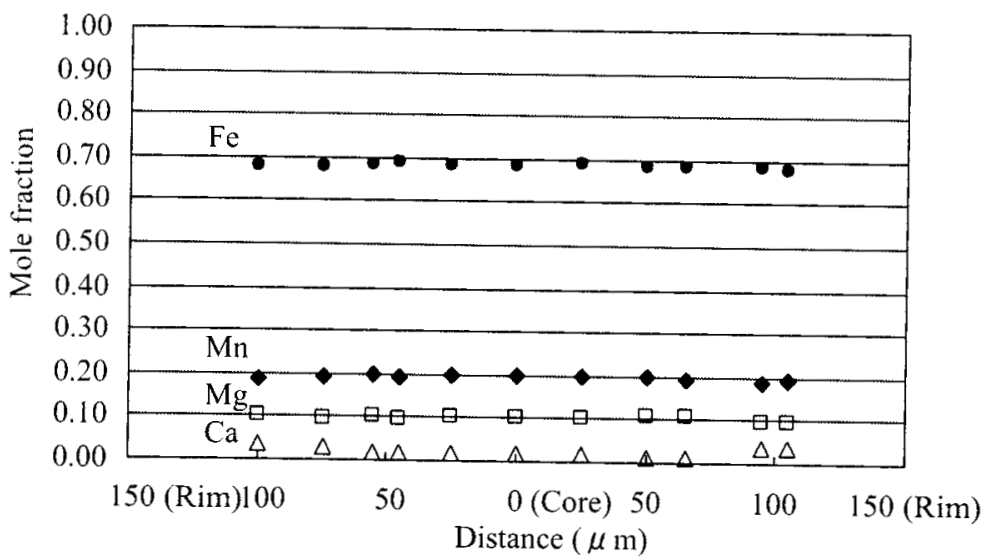

Sample B

Figure 8. Zoning profiles of garnet in pelitic schists from the Tagawa metamorphic rocks. (A) Zoning profile of large grains up to $1100 \mu \mathrm{m}$ which rarely occurs. (B) Zoning profile of small garnet less than $300 \mu \mathrm{m}$. This type of garnet commonly occurs. See Figure 6 for locations of samples A and B. 


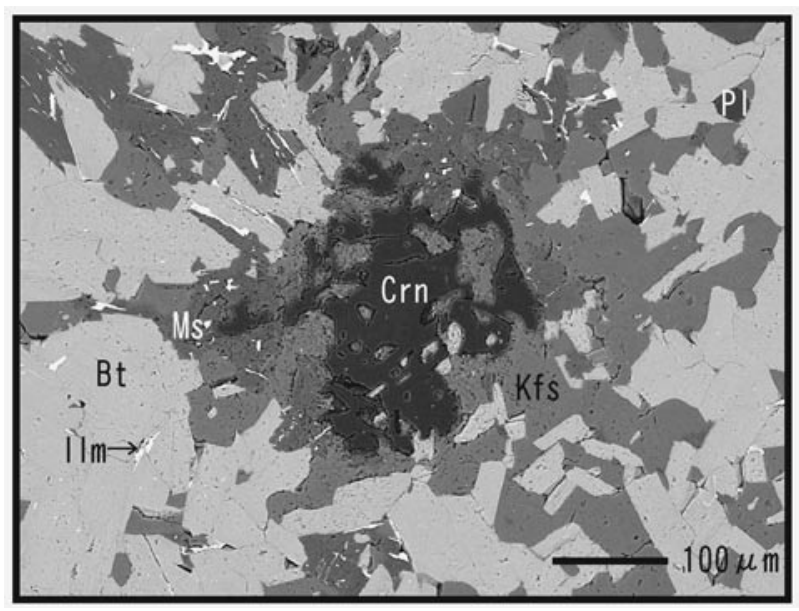

Figure 9. Back scattered electron image (BSEI) showing the occurrence of corundum which is surrounded by $\mathrm{K}$-feldspar and muscovite (Crn, corundum; Bt, biotite; Kfs, K-feldspar; Ms, muscovite).

hibit well developed metamorphic layering, and consist of quartz and plagioclase-rich as well as biotite rich layers. Representative mineral assemblages in the studied rocks are as follows.

(1) biotite + quartz \pm plagioclase

(2) biotite + quartz $+\mathrm{K}$-feldspar \pm plagioclase

(3) biotite + quartz $+\mathrm{K}$-feldspar + muscovite \pm plagioclase

(4) biotite + quartz + garnet $\pm \mathrm{K}$-feldspar \pm muscovite \pm plagioclase

(5) biotite + quartz + muscovite + plagioclase
(6) biotite + muscovite + plagioclase $+\mathrm{K}$-feldspar + corundum

Titanite, zircon, tourmaline, apatite and ilmenite occur as accessory minerals, and chlorite occurs as a secondary mineral. We did not identify any aluminosilicate mineral. Wollastonite occurs between pelitic and calcareous schists close to the Hirao granodiorite. Figure 6 shows a distribution of the mineral assemblages in the studied area, indicating the occurrence of garnet limited to a narrow region adjacent to the Hirao granodiorite.

The garnet is rich in $\mathrm{Mn}[\mathrm{Mn} /(\mathrm{Mn}+\mathrm{Fe}+\mathrm{Mg}+$ $\left.\mathrm{Ca}): \mathrm{X}_{\mathrm{Mn}}=0.17-0.24\right]$ and poor in $\mathrm{Ca}[\mathrm{Ca} /(\mathrm{Ca}+\mathrm{Fe}+$ $\left.\mathrm{Mg}+\mathrm{Mn}): \mathrm{X}_{\mathrm{Ca}}=0.01-0.05\right]$ as shown in Table 1 and Figure 7. Figure 8 shows representative chemical zoning patterns of garnet grains from samples A and B. Most of garnet grains are less than 300 micrometers in diameter and homogeneous, but some large grains up to $1100 \mathrm{mi}-$ crometers show a weak normal zoning. No reverse zoning was observed.

Biotite occurs in two modes in the whole studied area. In the vicinity of the granodiorite intrusion, reddish brown biotite occurs as a flaky crystal parallel to the metamorphic layering. Far from the granodiprite intrusion, small grains of greenish brown biotite replace large grains of muscovite along the cleavage or occur with random orientation in a muscovite-rich layer in the pelitic schists. Both biotites are interpreted as prograde metamorphic minerals.

Muscovite occurs widely and sporadically in the studied area. Neither muscovite nor K-feldspar shows a

Table 2. Composition of the constituent minerals of the corundum bearing pelitic schists in the Tagawa metamorphic rocks

\begin{tabular}{|c|c|c|c|c|c|c|c|c|}
\hline & Crundum & & & K-feldspar & Plagioclase & Muscovite & Biotite & \\
\hline $\mathrm{SiO}_{2}$ & & & & 62.65 & 56.64 & 44.91 & 31.75 & 32.09 \\
\hline $\mathrm{TiO}_{2}$ & 0.41 & 0.26 & & & & 1.66 & 3.93 & 4.02 \\
\hline $\mathrm{Al}_{2} \mathrm{O}_{3}$ & 98.81 & 98.38 & 98.59 & 18.79 & 26.81 & 33.81 & 20.96 & 21.54 \\
\hline $\mathrm{FeO}^{*}$ & 0.35 & & 0.33 & & & 1.89 & 24.19 & 23.69 \\
\hline $\mathrm{MgO}$ & & & & & & & 4.29 & 4.03 \\
\hline $\mathrm{CaO}$ & & & & & 8.92 & & & \\
\hline $\mathrm{Na}_{2} \mathrm{O}$ & & & & 0.75 & 6.48 & 0.2 & & \\
\hline $\mathrm{K}_{2} \mathrm{O}$ & & & & 17.44 & & 11.98 & 11.12 & 11.29 \\
\hline total & 99.57 & 98.64 & 98.92 & 99.63 & 98.89 & 94.46 & 96.24 & 96.65 \\
\hline $\mathrm{O}=$ & 3 & 3 & 3 & 8 & 8 & 11 & 22 & 22 \\
\hline Si & & & & 2.94 & 2.57 & 3.06 & 4.98 & 5.00 \\
\hline $\mathrm{Ti}$ & 0.01 & 0.00 & & & & 0.08 & 0.46 & 0.47 \\
\hline $\mathrm{Al}$ & 1.99 & 2.00 & 2.00 & 1.04 & 1.43 & 2.71 & 3.88 & 3.95 \\
\hline $\mathrm{Fe}$ & 0.00 & & 0.00 & & & 0.11 & 3.17 & 3.08 \\
\hline $\mathrm{Mg}$ & & & & & & & 1.00 & 0.94 \\
\hline $\mathrm{Ca}$ & & & & & 0.43 & & & \\
\hline $\mathrm{Na}$ & & & & 0.07 & 0.57 & 0.03 & & \\
\hline $\mathrm{K}$ & & & & 1.04 & & 1.04 & 2.23 & 2.24 \\
\hline total & 2.00 & 2.00 & 2.00 & 5.09 & 5.00 & 7.03 & 15.73 & 15.68 \\
\hline
\end{tabular}

* Total iron as FeO. 
Mg-Fe-Mn amphiboles

Diagram Parameters : $\left(\mathrm{Ca}+\mathrm{Na} \mathrm{B}_{\mathrm{B}}\right)<1.00 ;\left(\mathrm{Mg}, \mathrm{Fe}^{2+}, \mathrm{Mn}\right)_{\mathrm{B}} \geqq 1.00$

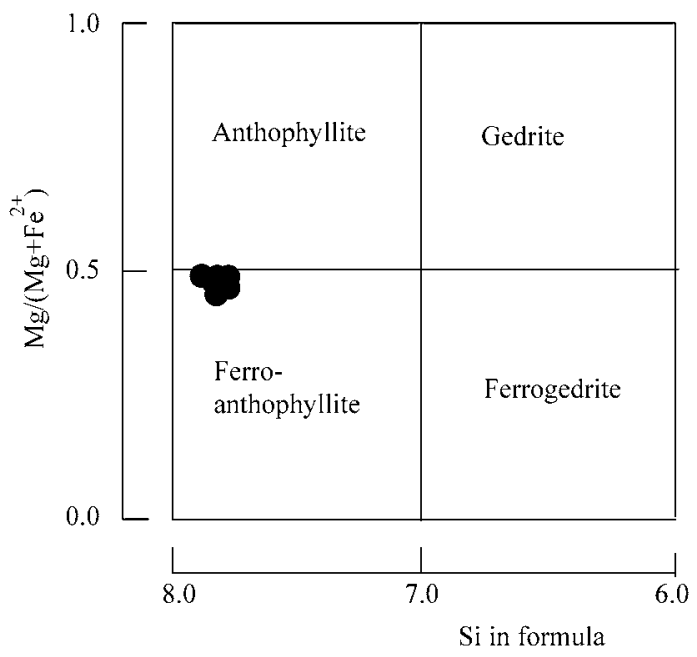

Calcic amphiboles

Diagram Parameters : $\left(\mathrm{CaB} \geqq 1.50 ;(\mathrm{Na}+\mathrm{K})_{\mathrm{A}}<0.50\right) ; \mathrm{CaA}<0.50$

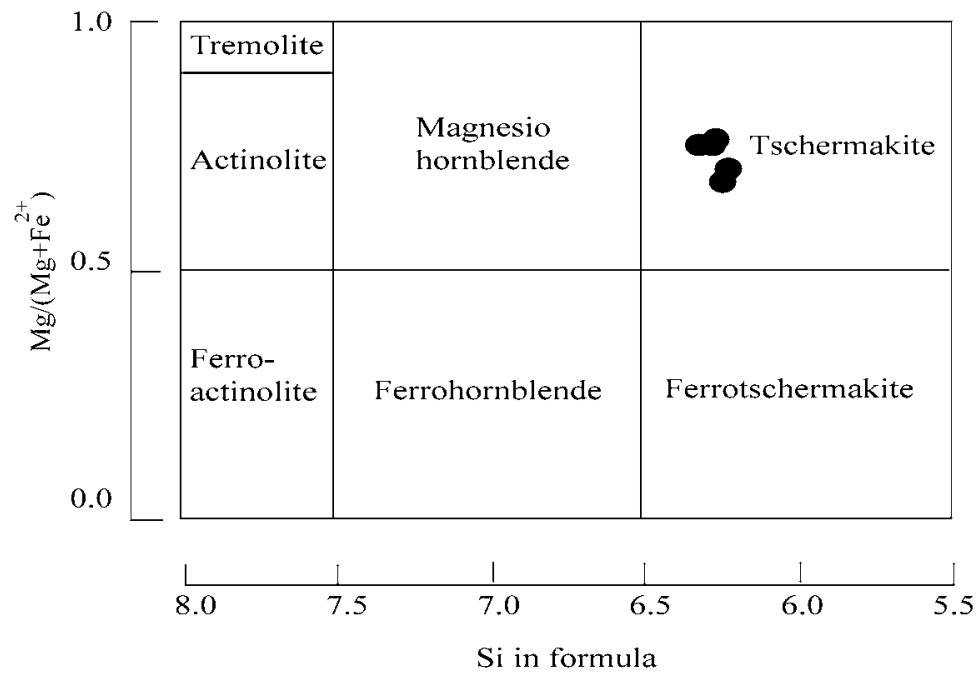

Figure 10. Compositions of anthophylite (above) and those of hornblende (below) (nomenclature of amphiboles after Leake et al., 1997).

systematic distribution in this area.

Corundum occurs in a quartz free layer of the pelitic schist at Goryosan, as an aggregate of about $0.5^{-1} \mathrm{~mm}$ in size surrounded by $\mathrm{K}$-feldspar and fine-grained muscovite (Fig. 9). The mineral assemblage is corundum $+\mathrm{K}^{-}$ feldspar + muscovite + plagioclase + biotite. This occurrence is comparable to that reported by Sawaki (1985) from the pelitic hornfels (contact metamorphosed Sangun Metamorphic Rocks) in the Hofu area, Yamaguchi Prefecture. Table 2 gives chemical analyses of minerals from the corundum-bearing pelitic schist. (b) Basic shists

Basic schists in this area are fine-grained schistose rocks. The rocks exhibit well developed metamorphic layering on the scale of several millimeters, consisting of quartz and plagioclase-rich and hornblende-rich layers. Wollastonite locally occurs at the contact between the basic schists and calcareous schists. Representative mineral assemblages are as follows.

(1) hornblende + quartz \pm plagioclase $\pm \mathrm{K}$-feldspar

(2) hornblende + clinopyroxene + quartz \pm plagioclase $\pm \mathrm{K}$-feldspar

(3) hornblende + anthophyllite $+\mathrm{K}$-feldspar + plagioclase 
Table 3. Representative analyses of anthophyllite from basic schist

\begin{tabular}{|c|c|c|c|c|c|c|c|}
\hline \multicolumn{8}{|l|}{ Anthophyllite } \\
\hline $\mathrm{SiO}_{2}$ & 53.37 & 51.65 & 51.81 & 52.26 & 51.77 & 51.96 & 50.87 \\
\hline $\mathrm{Al}_{2} \mathrm{O}_{3}$ & 1.04 & 1.35 & 0.81 & 1.15 & 1.89 & 1.3 & 1.51 \\
\hline $\mathrm{FeO}^{*}$ & 26.22 & 25.97 & 26.77 & 26.07 & 25.9 & 25.72 & 27.03 \\
\hline $\mathrm{MnO}$ & 0.98 & 0.97 & 1.22 & 1.01 & 1.22 & 1.02 & 1.18 \\
\hline $\mathrm{MgO}$ & 14.13 & 14.12 & 13.61 & 14.75 & 13.4 & 14.34 & 13.29 \\
\hline $\mathrm{CaO}$ & 1.32 & 0.63 & 0.7 & 0.78 & 1.72 & 0.95 & 0.76 \\
\hline total & 96.05 & 94.7 & 94.94 & 96.03 & 95.89 & 95.29 & 94.63 \\
\hline \multicolumn{8}{|c|}{ Cations on the basis of 23 Oxygens } \\
\hline $\mathrm{Si}$ & 7.94 & 7.92 & 7.97 & 7.91 & 7.87 & 7.9 & 7.87 \\
\hline $\mathrm{Al}^{\mathrm{IV}}$ & 0.06 & 0.08 & 0.03 & 0.09 & 0.13 & 0.1 & 0.13 \\
\hline $\mathrm{Al}^{\mathrm{VI}}$ & 0.13 & 0.16 & 0.12 & 0.11 & 0.21 & 0.13 & 0.15 \\
\hline $\mathrm{Fe}^{2+}$ & 3.32 & 3.33 & 3.44 & 3.30 & 3.29 & 3.27 & 3.50 \\
\hline $\mathrm{Mn}$ & 0.13 & 0.13 & 0.16 & 0.13 & 0.16 & 0.13 & 0.15 \\
\hline $\mathrm{Mg}$ & 3.19 & 3.23 & 3.12 & 3.33 & 3.03 & 3.25 & 3.06 \\
\hline $\mathrm{Ca}$ & 0.21 & 0.1 & 0.12 & 0.13 & 0.28 & 0.15 & 0.13 \\
\hline total & 14.98 & 14.95 & 14.96 & 15 & 14.97 & 14.94 & 14.99 \\
\hline $\mathrm{Mg} /\left(\mathrm{Mg}+\mathrm{Fe}^{2+}\right)$ & 0.49 & 0.49 & 0.48 & 0.50 & 0.48 & 0.50 & 0.47 \\
\hline
\end{tabular}

*Total iron as $\mathrm{FeO}$.

Table 4. Representative analyses of hornblende from anthophyllite bearing rock

Hornblende

\begin{tabular}{|c|c|c|c|c|}
\hline $\mathrm{SiO}_{2}$ & 41.75 & 42.39 & 42.47 & 42.22 \\
\hline $\mathrm{Al}_{2} \mathrm{O}_{3}$ & 15.20 & 14.61 & 14.15 & 14.83 \\
\hline $\mathrm{FeO}^{*}$ & 15.49 & 15.64 & 15.62 & 16.32 \\
\hline $\mathrm{MnO}$ & 0.57 & 0.61 & 0.56 & 0.53 \\
\hline $\mathrm{MgO}$ & 9.88 & 10.38 & 10.25 & 10.07 \\
\hline $\mathrm{CaO}$ & 10.05 & 10.04 & 9.93 & 9.80 \\
\hline $\mathrm{Na}_{2} \mathrm{O}$ & 2.68 & 2.52 & 2.38 & 2.30 \\
\hline total & 95.62 & 96.19 & 95.37 & 96.05 \\
\hline \multicolumn{5}{|c|}{ Cations on the basis of 23 Oxygens } \\
\hline $\mathrm{Si}$ & 6.22 & 6.26 & 6.33 & 6.24 \\
\hline $\mathrm{Al}^{\mathrm{N}}$ & 1.78 & 1.74 & 1.67 & 1.76 \\
\hline $\mathrm{Al}^{\mathrm{VI}}$ & 0.89 & 0.81 & 0.82 & 0.82 \\
\hline $\mathrm{Fe}^{2+}$ & 0.88 & 0.75 & 0.78 & 0.66 \\
\hline $\mathrm{Fe}^{3+}$ & 0.95 & 1.07 & 1.06 & 1.23 \\
\hline $\mathrm{Mn}$ & 0.07 & 0.08 & 0.07 & 0.07 \\
\hline $\mathrm{Mg}$ & 2.20 & 2.29 & 2.28 & 2.22 \\
\hline $\mathrm{Ca}$ & 1.61 & 1.59 & 1.59 & 1.55 \\
\hline${ }^{\mathrm{B}} \mathrm{Na}$ & 0.40 & 0.41 & 0.40 & 0.45 \\
\hline${ }^{\mathrm{A}} \mathrm{Na}$ & 0.37 & 0.31 & 0.38 & 0.21 \\
\hline total & 15.37 & 15.31 & 15.38 & 15.21 \\
\hline $\mathrm{Mg} /\left(\mathrm{Mg}+\mathrm{Fe}^{2+}\right)$ & 0.71 & 0.75 & 0.75 & 0.77 \\
\hline
\end{tabular}

${ }^{*}$ Total iron as $\mathrm{FeO}$. Ferric estimate made by total cation $-(\mathrm{Na}+$ Ca) $=13$. \pm clinopyroxene \pm garnet

Accessory minerals are titanite, zircon, tourmaline, and opaque minerals with secondary chlorite. Figure 10, Tables 3 and 4 show compositions of anthophyllite and those of hornblende from assemblage (3). Anthophyllite has $\mathrm{X}_{\mathrm{Mg}}\left[\mathrm{Mg} /\left(\mathrm{Mg}+\mathrm{Fe}^{2+}\right)\right]=0.47-0.50$ and $\mathrm{Si}=7.92^{-}$ 7.94. Hornblende has high tschermakitic compositions with $\mathrm{X}_{\mathrm{Mg}}=0.68-0.77$ and $\mathrm{Si}=6.22-6.33$. Garnet from assemblage (3) is enriched in grossular $\left(\mathrm{Pyp}_{1} \mathrm{Sps}_{7} \mathrm{Grs}_{92}\right)$. Clinopyroxene occurs in the calcareous basic schists and has compositions intermediate between diopside and hedenbergite $\left(\mathrm{X}_{\mathrm{Mg}}=0.40-0.66\right)$.

Distribution of the basic schist assemblages in the studied area is given in Figure 11. The occurrence of basic schists is very limited in the Tagawa metamorphic rocks and we could not find any systematic change of mineral assemblage in relation to the intrusion contact of the granodiorite.

\section{The Hirao Limestone and the basic dykes}

The Hirao Limestone is almost either pure or crystalline limestone. It has undergone extensive contact metamorphism within the limits of about $1 \mathrm{~km}$ from the intrusive contact with the Hirao granodiorite. Skarn minerals (grossular, vesuvianite, wollastonite and others) and ore deposits were developed in several places within the contact aureole of the Hirao granodiorite. Grain size of calcite in the limestone becomes coarser (up to several centimeters in diameter) towards the intrusive contact. The basic dykes were also metamorphosed together with 


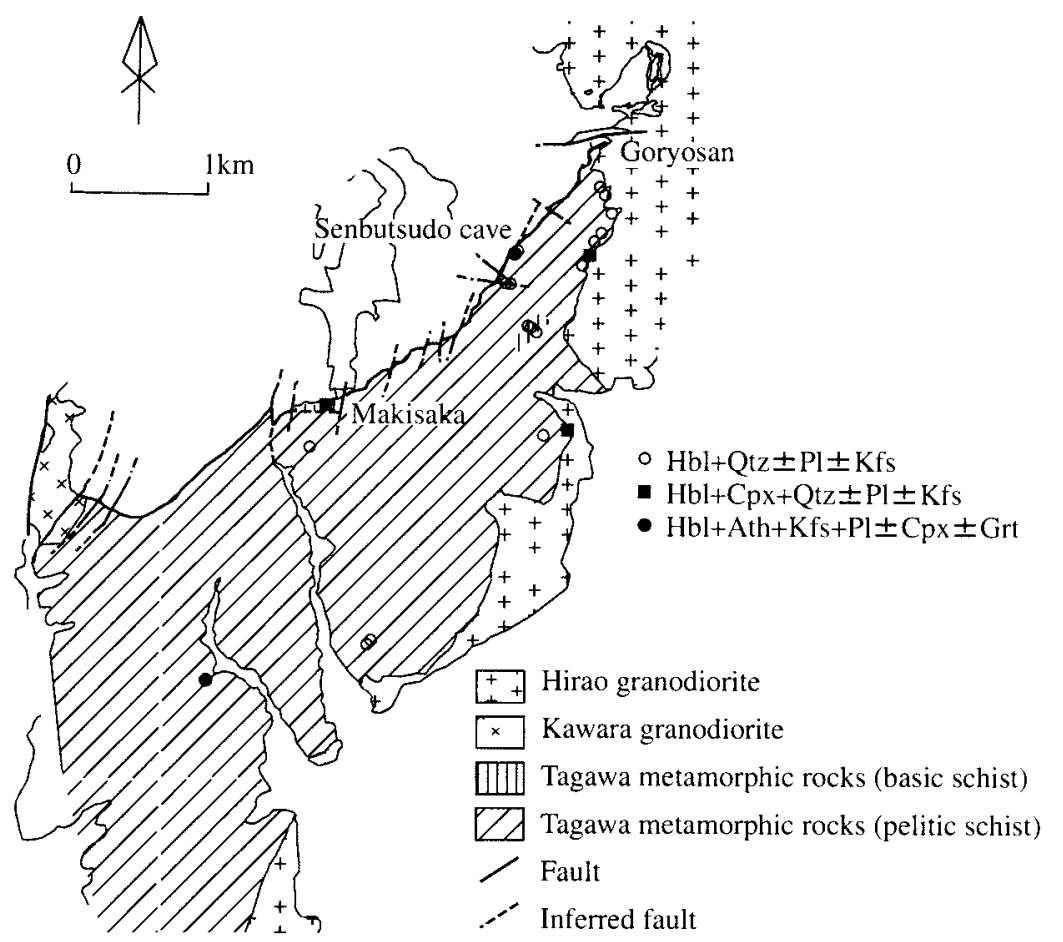

Figure 11. Distribution of the mineral assemblages of basic schists from the Tagawa metamorphic rocks. Abbreviations of mineral names after Kretz (1983). the surrounding limestone, resulting in the development of reaction zones between them. The reaction zone was briefly described by Fukuyama et al. (2002). The layer sequence is as follows: the metamorphosed basic dyke (biotite + diopside + plagioclase)-diopside zone (diopside + plagioclase: $1-2 \mathrm{~cm}$ thick)-garnet zone (grossular + clinozoisite + vesuvianite: $0.2-2 \mathrm{~cm}$ thick)-wollastonite zone ( wollastonite: $0.5-1 \mathrm{~cm}$ thick)-the crystalline limestone. Outside of the contact aureoles of the Hirao granodiorite, no reaction zone exists between the basic dykes and the limestone. The unmetamorphosed basic dykes are fine- to medium-grained holocrystalline rocks mainly consisting of hornblende and plagioclase with minor amounts of titanite and apatite. Hornblende frequently occurs as phenocrysts but plagioclase occurs only in the groundmass with the panidiomorphic texture. Although it is difficult to give a correct rock name without whole rock composition, we tentatively named it lamprophyre (sperssartite) based on its petrographical characteristics.

\section{Discussion}

\section{Geology and tectonics}

Occurrence of limestone blocks in the Kagumeyoshi Formation and the mingling structure at the north border of the Hirao Limestone strongly suggest that the rocks in the Kagumeyoshi Formation and the Hirao Limestone represent a tectonic collage of allochtonous bodies formed during accretion silimilar to the case of the Akiyoshi Limestone discussed by Kanmera and Nishi (1983).

At the southern border of the Hirao Limestone, it has a concordant field relationship with the uppermost part of the Tagawa metamorphic rocks. The fault relationship between them observed in many places is interpreted to have been formed by the later tectonic movements, which postdated the emplacement of the Hirao granodiorite. Therefore the Hirao Limestone and the uppermost part of the Tagawa metamorphic rocks are interpreted to belong to the same stratigraphic unit. The alternating occurrences of the Tagawa metamorphic rocks and the Hirao Limestone are indicative of a relatively calm sedimentary environment, such as coral reefs on a seamount. The occurrence of the limestone lenses in the uppermost part of the Tagawa metamorphic rocks may suggest their origin either as eroded blocks of limestone deposited at an outer reef or as an olistolith associated with the formation of the accretionary prism. Here we propose two possible interpretations. 1) The entire body of the Hirao Limestone and the uppermost part of the Tagawa metamorphic rocks could be a large olistolith formed during the accretion of the Paleozoic formation in this area. They were juxtaposed with rocks in the Kagumeyoshi Formation in the north and the original rocks of the other part of the Tagawa metamorphic rocks in the south. Then the southern part underwent the Sangun Metamorphism. This interpretation is based on the assumption that the Sangun Metamorphism fades out within the Hirao Limestone and 
that there is a tectonic boundary at the time of the accretion event between the uppermost and the main part of the Tagawa metamorphic rocks. 2) The Kagumeyoshi Formation, the Hirao Limestone and the uppermost part of the Tagawa metamorphic rocks represents a tectonic collage which has overlain the main part of the Tagawa metamorphic rocks as a nappe formed after the Sangun Metamorphism. This interpretation is based on the assumption that there is a low angle fault between the uppermost and the main part of the Tagawa metamorphic rocks.

In either interpretation, we have to assume the presence of a tectonic contact between the uppermost and the main part of the Tagawa metamorphic rocks, however poor surface exposures hampered detailed field observations of the relationship between these rocks.

\section{The dyke swarm}

Kiyohara (1968) divided the Hirao Limestone into four members (A-D) by using the clay layer as a key bed. He proposed that the lowermost member $\mathrm{A}$ is unconformably overlain by members $\mathrm{B}-\mathrm{D}$, and the presence of a double syncline structure in members B-D. We confirmed, however, that the clay layers are not sedimentary rocks but rather weathered dykes. Furthermore, we could not rec- ognize a large scale fold in the Hirao Limestone because the original bedding has not remained in most places and because there is no fossil record. Kiyohara's ideas of the unconformity and the double syncline structure are heavily based on the distribution of the clay layers. Therefore we conclude that his conclusion is not convincing.

Matsushita et al. (1969) had interpreted the basic dykes as hornfels and suggested that they were originally tuff or lavas. He further suggested that they were either sedimentary intercalations within the limestone or dykelike rocks squeezed out from the basement rocks and emplaced within the limestone during the folding of the Hirao Limestone. However, as shown in Figure 12, in the quarry wall at the Higashitani mine located in the western part of the Hiraodai, the basic rocks occur as platy bodies of several centimeters to several meters thick, striking NS$\mathrm{N} 60^{\circ} \mathrm{E}$ and dipping $70^{\circ} \mathrm{N}$ or $\mathrm{S}-90^{\circ}$. They show various structures such as bending, branching and lateral termination. Further they cut dark bands in the limestone at high angles which may show the original bedding. This occurrence clearly indicates that the basic rocks are metamorphosed basic dykes that intruded into the limestone prior to the contact metamorphism.

We interpreted that the dyke swarm was formed before the accretion because the occurrence of the dyke

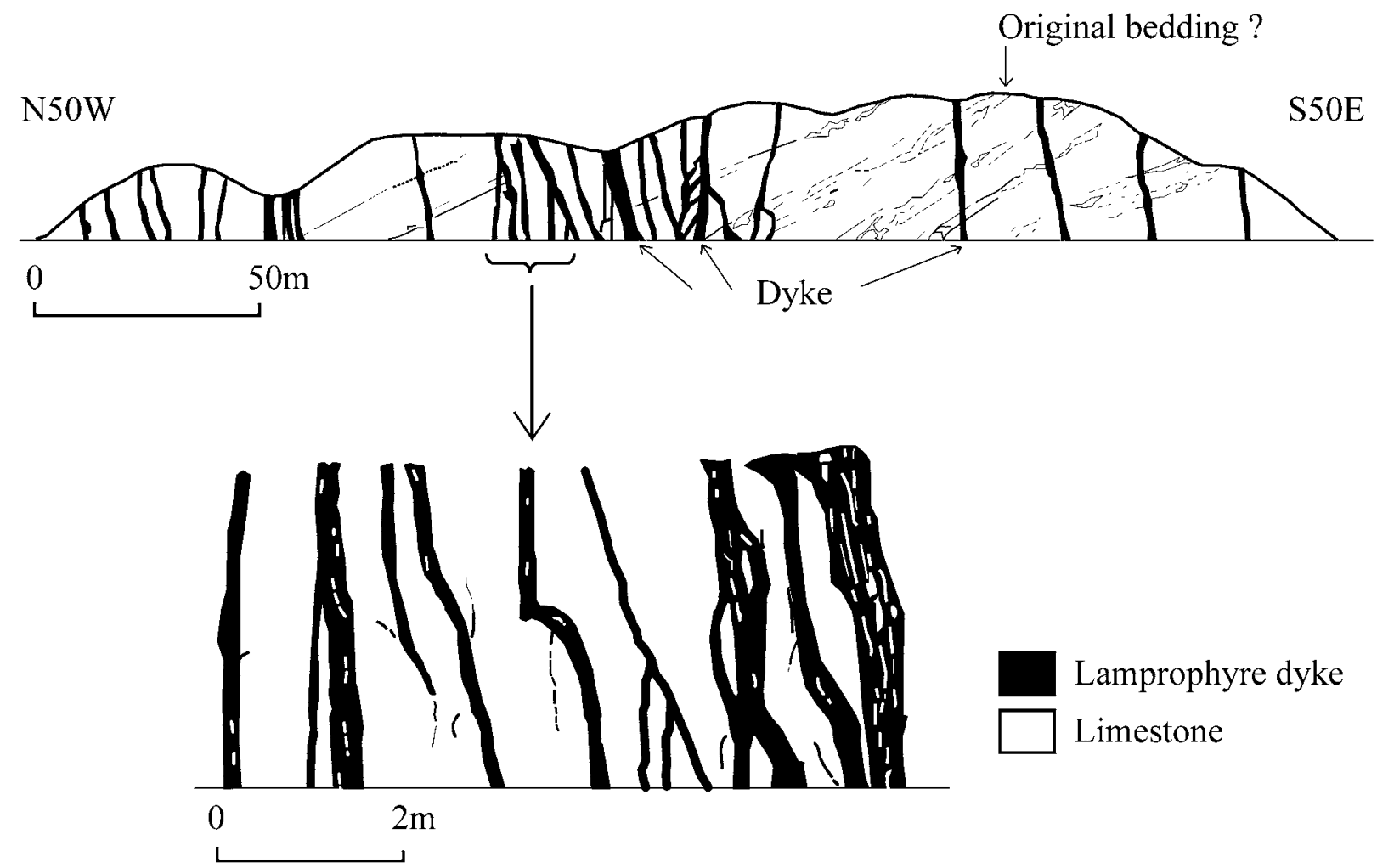

Figure 12. Sketch of the quarry wall at the Higashitani mine located in the western part of the Hiraodai (after Urata, 1987MS), showing the lamprophyre dyke swarm in the Hirao Limestone. 
swarm is limited to within and near the Hirao Limestone. It may have been formed at the seamount on which the Hirao Limestone was deposited.

\section{Metamorphic conditions}

The occurrence of garnet is limited in the vicinity of the granodiorite intrusion indicating that the garnet is a product of contact metamorphism. Coexistence of garnet with $\mathrm{K}$-feldspar (Fig. 13) has not been reported from regionally metamorphosed rocks of the Sangun Metamorphic Rock (e.g. Nishimura, 1971). However, this assemblage has been reported from rocks in contact metamorphic aureoles such as the Tono and the Tanohata (OkuyamaKusunose, 1994 and 1999) in the Tohoku province.

We interpreted biotite in the studied rocks as a product of contact metamorphism for the following reasons. 1) The Sangun Metamorphic Rocks are believed not to have reached the biotite grade by the study of Nishimura (1971) at the Nishikicho area where they have not undergone the contact metamorphism. 2) The grain size of biotite increases towards the intrusive contact of the granodiorite. 3) The color of the biotite changes from greenish brown to reddish brown towards the intrusive contact of the granodiorite, which is comparable to the features suggested as evidence of contact metamorphism by Karakida (1965). We have not observed any mineralogical features such as the presence of alkali amphibole, suggestive of Sangun Metamorphism. However, the assemblage of muscovite + albite + quartz in the pelitic schist would be the product of the Sangun Metamorphism, because the muscovite is replaced by the biotite, which is likely a product of contact metamorphism. Parallel alignment of biotite grains may be formed by mimetic crystallization. Thus widespread occurrences of biotite in the pelitic schists and hornblende in the basic schists represent contact metamorphic overprints on the regionally metamorphosed precursors.

The diopsidic clinopyroxene in the calcareous basic schists is also a product of contact metamorphic reaction as;

tremolite +2 quartz +3 calcite

$=5$ diopside $+3 \mathrm{CO}_{2}+\mathrm{H}_{2} \mathrm{O}$,

This reaction takes place at $400-650^{\circ} \mathrm{C}$ in a pressure range of $150-500 \mathrm{MPa}$ depending on the fluid composition (e.g. Winkler, 1974 and Nabelek, 2002).

\section{(a) Garnet-biotite geothermometers}

Garnet coexists with biotite in the pelitic schists in the regions near the Hirao granodiorite (Fig. 6). Relatively small grain size and chemical homogeneity of the garnet grains may indicate a short duration of the peak metamorphic condition appropriate for garnet growth, which is advantageous for the estimate of the equilibrium $P-T$ condition by using garnet-biotite geothermometers.

Rim compositions of the garnet grains and those of the biotite grains adjacent to them were used for garnetbiotite $P-T$ calculations. We employed the following six geothermometers: Ferry and Spear (1978), Ganguly and Saxena (1984), Hodges and Spear (1982), Dasgupta et al. (1991), Holdaway et al. (1997), Holdaway (2000). Figure 14 gives the results for the sample G (Table 1). The geothermometers by Dasgupta et al. (1991) and by Ganguly and Saxena (1984) give relatively lower temperatures than those obtained by the other four geothermometers, which are almost consistent with each other. The difference may result from a small value of excess interaction

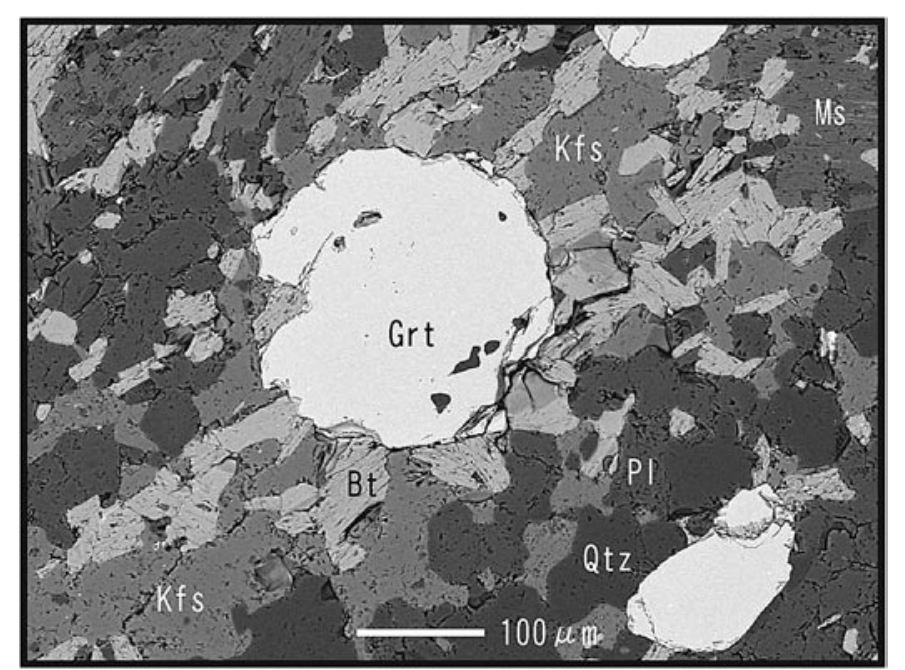

Figure 13. Back scattered electron image (BSEI) of sample F (Table 1 and Figure 6) showing coexistence of garnet, biotite, K-feldspar and plagioclase. 


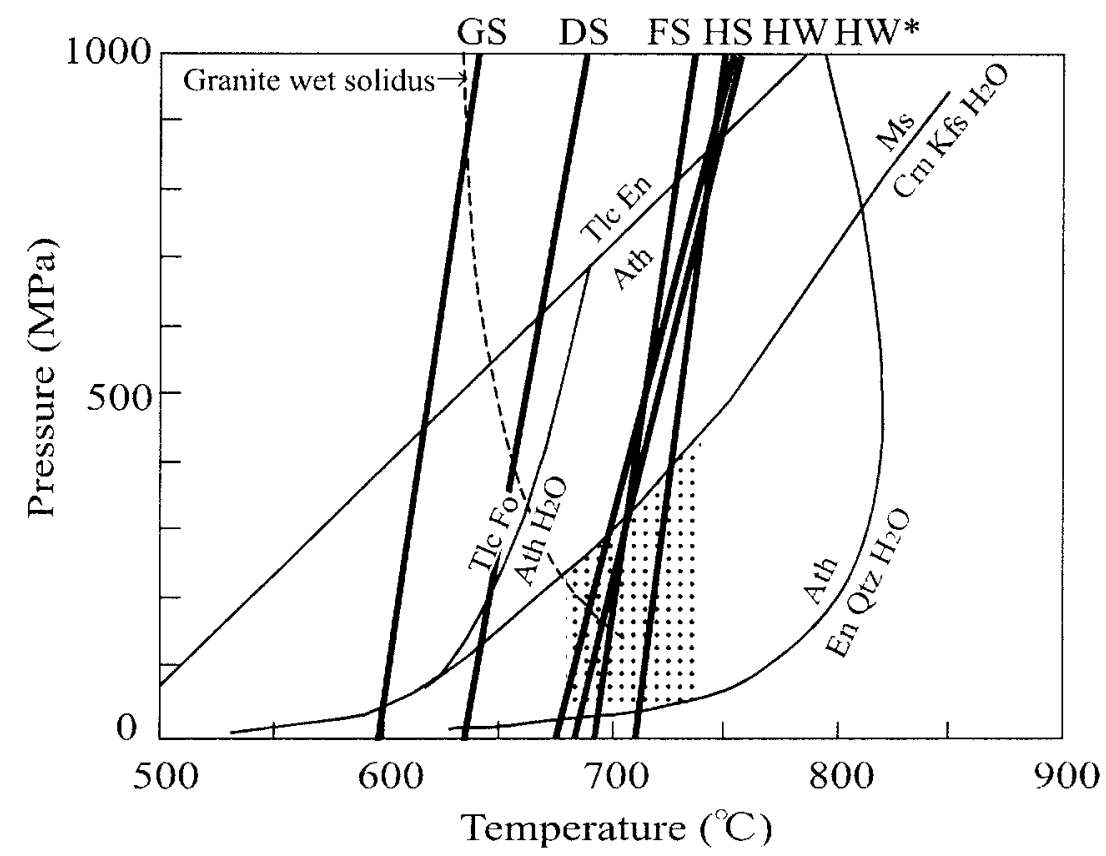

Figure 14. Pressure-temperature condition of the contact metamorphism. The dotted area shows the probable peak metamorphic condition constrained by garnet-biotite geothermometers, the muscovite (MS) breakdown reaction and the stability field of anthophyllite (Ath). Granite wet solidus after Johannes (1984). Geothermometers are Ferry and Spear (1978), FS; Hodges and Spear (1982), HS; Ganguly and Saxena (1984), GS; Dasgupta et al. (1991), DS; Holdaway et al. (1997), HW; Holdaway et al. (2000), HW*. Univariant reactions calculated with THERMOCALC (Holland and Powell, 1998).

parameter of $\mathrm{Mn}$ in garnet and nonideal term in biotite adopted by the former two methods. The latter four methods give almost the same temperature of around $700^{\circ} \mathrm{C}$. The consistency may come from the relatively $\mathrm{Ca}$-poor nature of the garnet studied and hence the nonideal term with respect to $\mathrm{Ca}$ is not effective in the present case.

(b) Breakdown reaction of muscovite

The occurrence of corundum in the pelitic schist gives significant information for the pressure-temperature estimation. Corundum is mantled by $\mathrm{K}$-feldspar and muscovite, indicating the following reaction as suggested by Sawaki (1985):

$\mathrm{KAl}_{3} \mathrm{Si}_{3} \mathrm{O}_{10}(\mathrm{OH})_{2}=\mathrm{Al}_{2} \mathrm{O}_{3}+\mathrm{KAlSi}_{3} \mathrm{O}_{10}+\mathrm{H}_{2} \mathrm{O}$
Muscovite Corundum K-feldspar Water

Orthoclase (Or) component in the $\mathrm{K}$-feldspar surrounding corundum is over 96 mole $\%$, consistent with this reaction. Coexistence of corundum $+\mathrm{K}$-feldspar + muscovite suggests the pressure-temperature condition on the univariant curve of the above reaction (Fig. 14).

(c) Stability of anthophyllite

The stability field of anthophyllite is bounded by the following two reactions:

$9 \mathrm{Mg}_{3} \mathrm{Si}_{4} \mathrm{O}_{10}(\mathrm{OH})_{2}+4 \mathrm{Mg}_{2} \mathrm{SiO}_{4}=5 \mathrm{Mg}_{7} \mathrm{Si}_{8} \mathrm{O}_{22}(\mathrm{OH})_{2}+4 \mathrm{H}_{2} \mathrm{O}$ Talc Forsterite Anthophyllite Water and

\section{$\mathrm{Mg}_{7} \mathrm{Si}_{8} \mathrm{O}_{22}(\mathrm{OH})_{2}=7 \mathrm{MgSiO}_{3}+\mathrm{SiO}_{2}+\mathrm{H}_{2} \mathrm{O}$ \\ Anthophyllite Enstatite Quartz Water}

Anthophyllite in the studied basic schist coexists neither with orthopyroxene nor with quartz, indicating that the pressure-temperature condition is within the stability field of anthophyllite.

To evaluate the effect of ferro-anthophyllite component, two univariant curves were calculated with THERMOCALC; one for the breakdown reaction of anthophyllite and the other for the ferro-anthophyllite. The temperature difference between them is only about $20^{\circ} \mathrm{C}$.

\section{(d) $P-T$ conditions of the contact metamorphism}

The garnet-biotite geothermometers, the muscovite breakdown reaction and the stability filed of anthophyllite discussed above are combined to estimate the peak pressure-temperature condition of contact metamorphism in the studied area.

As shown in Figure 14, all the studied equilibria consistently indicate a temperature of $700^{\circ} \mathrm{C}$ except for the results obtained by the geothermometers of Dasgupta et al. (1991) and by Ganguly and Saxena (1984). The pressure is poorly constrained to be lower than about $800 \mathrm{MPa}$ estimated from the intersection of muscovite and anthophyllite breakdown reactions (Fig. 14). However, if we specify the temperature at $\sim 700^{\circ} \mathrm{C}$, then the pressure will be reduced as low as $300 \mathrm{MPa}$. This estimated pressure- 
temperature condition is comparable to those in the highest grades of other contact aureoles around the Cretaceous granites in Japan such as the Tono (Okuyama-Kusunose, 1994) in the Kitakami Massif and the Daimonji (Nakamura, 1996) in Kyoto.

\section{Conclusions}

We presented following several arguments for the origin of the Hirao Limestone and the Kagumeyoshi Formation as a tectonic collage associated with terrane accretion.

1) Occurrence of limestone blocks in the Kagumeyoshi Formation and the mingling structure at the north border of the Hirao Limestone.

2) The concordant relationship between the Hirao Limestone and the uppermost part of the Tagawa metamorphic rocks.

3) Exclusive occurrence of the dyke swarm within the Hirao Limestone.

We consider that the Hirao Limestone and the uppermost part of the Tagawa metamorphic rocks represent a sedimentary sequence deposited on a seamount, which later collapsed to and emplaced into an accretionary prism and mingled with the Kagumeyoshi Formation.

As for the juxtaposition of the tectonic collage and the main part of the Tagawa metamorphic rocks, two models were discussed; they are related each other with a tectonic contact formed at the time of accretion, or they are related with a nappe formed after the Sangun Metamorphism.

We could not identify any mineralogical feature indicative of the Sangun Metamorphism since all the rocks studied were thermally metamorphosed by the Hirao granodiorite intrusion. The estimated peak $P-T$ condition of contact metamorphism is comparable to those reported from other contact metamorphic aureoles associated with Cretaceous granites in Japan.

\section{Acknowledgements}

We are grateful to Dr. H. Isobe for his assistance in EDS analyses at Kumamoto University. Careful readings of the manuscript and constructive reviews by Dr. Y. Okuyama and an anonymous reviewer were very helpful. We also thank Dr. M. Arima for his suggestions and editorial handling. This work has been financially supported by Japan Society for the Promotion of Science (Grant No. 11304038 to T.N.).

\section{References}

Dasgupta, S., Sengupta, P., Guha, D. and Fukuoka, M. (1991) A refined garnet-biotite $\mathrm{Fe}-\mathrm{Mg}$ exchange geothermometer and its application in amphibolites and granulites. Contributions to Mineralogy and Petrology, 109, 130-137.

Ferry, J.M. and Spear, F.S. (1978) Experimental calibration of the partitioning of $\mathrm{Fe}$ and $\mathrm{Mg}$ between biotite and garnet. Contributions to Mineralogy and Petrology, 66, 113-117.

Fukuyama, M., Nishiyama, T. and Urata, K. (2002) Reaction zones and composite veins around the metamorphosed basic dykes in the Hirao limestone, Fukuoka, Japan. Geochimica et Cosmochimica Acta, 66, No. S1, A250.

Ganguly, J. and Saxena, S.K. (1984) Mixing properties of aluminosilicate garnets: Constraints from natural and experimental data, and applications to geothermobarometry. American Mineralogist, 69, 88-97.

Hara, I. (1982) Evolutional processes of paired metamorphic belts - Hida Belt and Sangun Belt -, the Memoirs of the Geological Society of Japan, No. 21, 71-89.

Hase, A. and Nishimura, Y. (1979) Greenstones in the Chugoku district. The Journal of the Geological Society of Japan, 85, No. 7, 401-412 (in Japanese with English abstract).

Hayasaka, Y. (1985) Tectonics of the Sangun belt, Southwest Japan. Prof. H. Yoshida Memorial Volume, 339-354 (in Japanese).

Hodge, K.V. and Spear, F.S. (1982) Geothermometry, geobarometry and the $\mathrm{Al}_{2} \mathrm{SiO}_{5}$ triple point at Mt.Moosilauke, New Hampshire. American Mineralogist, 67, 1118-1134.

Holdaway, M.J., Mukhopadhyay, B., Dyar, M.D., Guidotti, C.V. and Dutrow, B.L. (1997) Garnet-biotite geothermometry revised:new Margules parameters and a natural specimen data set from Maine. American Mineralogist, 82, 582-595.

Holdaway, M.J. (2000) Application of new experimental and garnet Margules data to the garnet-biotite geothermometer. American Mineralogist, 85, 881-892.

Holland, T.J.B. and Powell, R. (1998) An internally-consistent thermodynamic data set for phases of petrological interest. Journal of Metamorphic Geology, 16, 309-343.

Ishiga, H. (1984) Follicucullus (Permian Radioralia) from Maizuru Group in Maizuru Belt, Southwest Japan. Chikyu Kagaku, 38, 427-434.

Johannes, W. (1984) Beginning of melting in the granite system $\mathrm{Qz}-\mathrm{Or}-\mathrm{Ab}-\mathrm{An}-\mathrm{H}_{2} \mathrm{O}$. Contributions to Mineralogy and Petrology, 86, 264-273.

Kanmera, K. and Nishi, H. (1983) Accreted oceanic reef complex in southwest Japan. In Accretion Tectonics in the Circum -Pacific Regions (Hashimoto, M. and Uyeda, S. Eds.). pp. 358, Terra Scientific Publishing Co., Tokyo, 195-206.

Kawano, Y. and Ueda, Y. (1966) K-A dating on the igneous rocks in Japan (IV) - Granitic rocks in northeastern Japan -. Journal of mineralogy, petrology and economic geology, 56, 191211.

Kretz, R. (1983) Symbols for rock-forming minerals. American Mineralogist, 68, 277-279.

Kinoshita, K. (1953) Hirao-dai Plateau. Hirao-dai Karst No. 2. Kokura City. 1-32.

Kinoshita, K., Okamoto, Y., Matsumoto, M. and Miyahisa, M. (1954) Mineral locality around Hirao-dai in Kitakyushu and Sanno-dake. Field Guidbook. Kokura City. 1-50.

Kiyohara, K. (1968) Geological structure of the Hirao limestone 
group in the Hirao plateau of the northern Kyushu, Japan. Bulletin of the Geological Survey of Japan, 19, 471-480.

Leake, B.E., Woolley, A.R., Arps, C.E.S., Birch, W.D., Gilbert, M.C., Grice, J.D., Hawthorne, F.C., Kato, A., Kisch, H.J., Krivovichev, V.G., Linthout, K., Laird, J., Mandarino, J.A., Maresch, W.V., Nickel, E.H., Rock, N.M.S., Schumacher, J.C., Smith, D.C., Stephenson, N.C.N., Ungaretti, L., Whittaker, E.J.W. and Youzhi, G. (1997) Nomenclature of amphiboles: report of the subcommittee on amphiboles of the international mineralogical association, commission on new minerals and mineral names. American Mineralogist, 82, 1019-1037.

Matsumoto, T. (1951) An outline of the fundamental geologic structure in north Kyushu and west Chugoku. The Science Reports of the Faculty of Science Kyushu University, Geology, 3, 37-48.

Matsushita, H. (1971) A study on the formation of the depositional basins of the coal-fields in Kyushu. Science Reports Department of Geology Kyushu University, 11, no. 1, 1-16.

Matsushita, H., Nagai, T. and Kaneko, N. (1969) The geological structure of Hiraodai and its neighbourhood, Fukuoka Prefecture (The geological structures of northern Kyushu, Part 1). The Science Reports of the Faculty of Science, Kyushu University, Geology, 9, 113-119.

Nabelek, P.I. (2002) Calc-silicate reactions and bedding-controlled isotopic exchange in the Notch Peal arureole, Utah: implications for differential fluid fluxes with metamorphic grade. Journal of Metamorphic Geology, 20, 429-440.

Nakamura, D. (1996) On garnet-biotite geothermometer: Application to the Sanbagawa and the Daimonji metamorphic rocks ad it's evaluation. Jornal of Mineralogy, Petrology and Economic Geology, 91, 165-176 (in Japanese with English abstract).

Nishimura, Y. (1971) Regional metamorphism of the Nishikicho district, Southwest Japan. Journal of Science of the Hiroshima University, Series C, 6, 203-268.

Nishimura, Y. (1998) Geotectonic subdivision and areal extent of the Sangun Belt, Inner Zone of Southwest Japan. Journal of
Metamorphic Geology, 16, 129-140.

Nishimura, Y., Inoue, T. and Yamamoto, H. (1977) Sangun Belt, with special reference to the stratigraphy and metamorphism. In The Sanbagawa Belt (Hide, K. Ed.). pp. 440, Hiroshima Univ. Press, 257-282 ( in Japanese with English abstract).

Nishiyama, T. (1989) Kinetics of hydrofracturing and metamorphic veining. Geology, 17, 1068-1071.

Nureki, T. (1969) Geological relations of the Sangun Metamorphic Rocks to the "non metamorphic" Paleozoic formations in the Chugoku Province. The Memoirs of the Geological Society of Japan, No.4, 23-39 (in Japanese with English abstract).

Okuyama-Kusunose, Y. (1994) Phase relations in andalusite-sillimanite type $\mathrm{Fe}$-rich metapelites: Tono contact metamorphic aureole, northeast Japan. Journal of Metamorphic Geology, $12,153-168$.

Okuyama-Kusunose, Y. (1999) Contact metamorphism in the aureole around the Tanohata plutonic complex, northern Kitakami Massif, Northeast Japan; depth of magma chamber of Cretaceous plutonic rocks. Jornal of Mineralogy, Petrology and Economic Geology, 94, 203-221 (in Japanese with English abstract).

Sawaki, T. (1985) Corundum-bearing pelitic hornfels in the Hofu area, Yamaguchi Prefecture. The Journal of the Geological Society of Japan, 91, 719-722 (in Japanese).

Urata, K. (1987MS) Geological and petrological study on the Hirao limestone, Fukuoka Prefecture. pp.35. Graduation thesis of Kyushu University.

Urata, K., Fujii, A., Yoshimura, K. and Inokura, Y. (1997) Karst hydrology of Hirao-dai plateau, Fukuoka prefecture, southwestern Japan. Field Guidebook for $104^{\text {th }}$ Annual Meeting in Fukuoka, Geological Society of Japan, 189-216.

Winkler, H.G..F. (1974) Petrogensis of metamorphic rocks. pp.320. Springer-Verlag, Berlin.

Manuscript received; 19 September, 2003

Manuscript accepted; 20 February, 2004 